\title{
Da'i Credibility in The Post-Truth Era: A Study of Da'i in Surabaya
}

\author{
Maulidatus Syahrotin Naqqiyah ${ }^{*} \&$ Ali Nurdin \\ Faculty of Da'wah and Communication, UIN Sunan Ampel Surabaya \\ *Email:maulinaqqy@gmail.com
}

\begin{abstract}
The development of media technology and the level of one's ability to use social media to be one of the triggers for the birth of the post-truth era, an era in which too much truth will become a lie. Da'wah in the post-truth era requires the credibility of a competent preacher to bring people back so that they are not lulled by the flow of technological development. This study aims to describe the methods of da'i (Islamic preachers) in building and increasing their credibility in the post-truth era in Surabaya. The study conducted by descriptive-qualitative and the data collection techniques used interview and observation. Data were analyzed by the perspective of the source credibility theory. The results of study describe that building and increasing its credibility, a da'i uses several methods applied in preaching in the post-truth era by including his scientific 'sanad' clearly, using the main literature as reference material such as classic books that are synergized with contemporary literature (internet), having written works that have been published, and sorting diction messages in accordance with mad'u or the communicant situation.
\end{abstract}

Keywords: Credibility; Da'i; Post-Truth

\begin{abstract}
ABSTRAK
Perkembangan teknologi media dan tingkat kemampuan seseorang dalam menggunakan media sosial menjadi salab satu pemicu labirnya era post-truth, yaitu era di mana sebuah kebenaran yang terlampau berlebihan akan menjadi sebuah kebohongan. Dakwah di era post-truth memerlukan kredibilitas seorang da'i yang kompeten untuk membawa kembali masyarakat agar tidak terlena oleh arus perkembangan teknologi. Penelitian ini bertujuan untuk mendeskripsikan cara da'i dalam membangun dan meningkatkan keredibilitasnya di era post-truth di Surabaya. Penelitian dilakukan dengan jenis deskriptif-kualitatif dan teknik pengumpulan data dengan wawancara dan pengamatan. Data dianalisis dengan perspektif teori kredibilitas sumber. Hasil penelitian mendeskripsikan bahwa dalam membangun dan meningkatkan kedibilitasnya, seorang da'i menggunakan beberapa cara yang diterapkan dalam berdakwah di era post-truth yaitu dengan menyertakan sanad keilmuan yang dimilikinya dengan jelas, menggunakan literatur utama sebagai referensi materi, seperti kitab-kitab klasik yang disinergikan dengan literatur kekinian (internet), memiliki hasil karya tulis yang telah dipublikasikan, dan pemiliban diksi pesan yang sesuai dengan keadaan mad'unya.
\end{abstract}

Kata kunci : Kredibilitas; Da';; Post-Truth 


\section{INTRODUCTION}

The tendency of society in the use of social media has been a contributor to the emergence of post-truth over the past few years. Starting from the appearance of political elites in various corners of the world in manipulating people's paradigms by spreading evil gossip about their opponents and assuming little evidence to emerge a duping society. Along with the development of technology and the development of the level of people's ability to use social media, propaganda activities can be done through social media. All elements of community life have resonated with the emergence of new media, even social media is very dominating in human life. Therefore, it is very natural when the influence of the internet and also the very diverse social media platforms cause the widespread spread of false news (Hartono, 2018, p.71)

The rapid flow of information in the current digital revolution era raises many problems in the life of the media and society. The problems that occur in society today are no longer about how they get information, but the lack of ability to understand the information they receive. Conventional media have strong credibility and role in the flow of information and are even accompanied by political interests. This situation requires the audience to look for alternative information (Syuhada, 2018, p.76). Another problem that is being experienced by the community at the moment is the poor media literacy owned by the community. This problem is a factor in the gap between media information and understanding of information received by the public. This gap causes the community to be unable to weigh, choose and sort, even to judge which information is really real and which is not (Hartono, 2018, p.70).

The term post-truth is not only synonymous with the meaning of posttruth, but something that goes beyond the truth. When something goes beyond the truth, what appears is a lie, pretense, and false opinions. The increase in hoaxes on social media is a fact of the post-truth era. The statements of politicians who are filled with lies make the media waver in preaching (Mcintyre, 2018, p.7).

The term post-truth became more popular when the Oxford dictionary made it the "Word of the Year" in 2016. The popularity of this term is calculated based on the number of uses of the term post-truth in 2016 which increased by $2000 \%$ from 2015. The increasing use of the term post-truth is based on the political events in 2016 that influenced the world view, namely the British Exit (Brexit), the departure of the United Kingdom from the European Union and Donald Trump was elected president of the United States. Post-truth is defined as the Oxford dictionary as a condition where facts do not have much influence in shaping public opinion than personal emotions and beliefs (Hartono, 2018, p.73). The existence of the post-truth regime discourse in Indonesia began with 
President Jokowi's statement about the political atmosphere that was lined with repeated hoaxes so that post-truth happened (Jatmiko, 2019, p.21). Lee Mcintyre in his book Post-Truth also said that the emergence of post-truth originated from generations who have academic abilities at the level of college students. And it is very ironic when the academic ability is misused to spread a lie (Mcintyre, 2018, p.123). Academics who are believed by the public to have a broad enough level of knowledge, to be able to create breakthroughs for the development of society, have indirectly made changes in such a way as the emergence of the current posttruth era.

Simply put, the post-truth era can be understood by exceeding the truth so that lies appear widely spread in the community (Mcintyre, 2018, p.13). Post-truth, which initially only revolved around the world of politics, has now penetrated the world of da'wah and has become problematic for preachers in da'wah. Da'wah is the delivery of a message from a communicator $\left(d a^{\prime} \imath\right)$ to the communicant (mad'u) that is expected to emerge positive effects afterward. The emergence of positive effects from the occurrence of this communication process is inseparable from how the communicator in delivering or packaging the contents of preaching. The most important thing in a communication process is the message conveyed by the communicator $\left(d a^{\prime} l\right)$ can be understood and understood by the communicant (mad'u). Communication events occur if there is a source of information (preachers) conveying propaganda messages that can provide stimuli or responses in symbols in the form of verbal symbols (words, language) or nonverbal (nonwords) for the communicant (mad'u) (Mulyana, 2008, p.3). Da' $i$ has a great responsibility for what is said or preached. In addition to being based on the content or the contents of the da'wah, a communicator or preacher also takes into account his credibility. The more widespread preaching on social media, and the more sophisticated level of public knowledge about social media, then it makes a preacher need to increase his credibility to attract the attention of the audience and his message is used as a reference for the audience.

For a preacher, credibility is a major factor and is very important to have, because the mad'u or the communicant himself will determine whether he will follow the teachings, and also the advice of the preacher. Da'wah is not only oriented towards the interests of preachers, but also the needs of the community or mad'u (Hariyanto, 2018, p.62). Society or the public has a variety of expectations of preachers. This is what requires a preacher to increase credibility and have internal capabilities both at the level of science, communication skills, and also self-mastery (Hariyanto, 2018: 64). The ability of science is one of the efforts in increasing the credibility of a preacher. Each preacher has a different way of communication in conveying his knowledge to preach. So that is what is easily remembered by the public or the public to make the preacher role models or public idols.

Aristotle provides an indicator of credibility through the characters inherent 
in ethos, pathos and logos. These three characters can be owned by a preacher. Ethos is a strength that must be possessed by the preacher based on his character so that the message conveyed can be trusted by the target of preaching ( ad $^{\prime} u$ ). Pathos is a power that must be possessed by a preacher to control the emotions of his preaching people. Logos is the power possessed by preachers in providing the rational arguments they convey (Sigar, Londa, \& Tulung, 2017, p.6). Credibility of a preacher as a communicator can come from competence, attitude (character), goals (intention), personality (personality) and dynamics (dynamism) (Cangara, 2008, p.92). Competence is the credibility of the preacher (communicator) in the form of mastery of the problem or topic being discussed. Attitude (character) is the appearance of a preacher who shows as a person who is strong or tolerant in principle. Purpose (intention) is everything that is done by a preacher must contain good intentions and goals. Personality (personality) is the appearance of a preacher who shows a warm and friendly personality. Ddynamism is the delivery of a preacher's message that shows an effort to attract the attention of the audience ( $\operatorname{mad}^{\prime} u$ ) in various ways so that the audience continues to follow the direction of preaching (Beebe \& Beebe, 2005, p.420).

Credibility in the study of communication science is not something new. Onong Uchana Effendy (2000, p.305) said that in the form of a communication process, a communicator will succeed if he successfully shows the source of credibility, meaning that it becomes a source of trust for the communicant to the communicator in his work and whether or not to be trusted. Hovlan described the role of credibility in the process of receiving messages by arguing that experts would be more persuasive compared to non-experts. A persuasive message will certainly be more effective if it is known that the messenger is an expert in his field (Saifuddin, 1995, p.76). In this case, the knowledge and expertise of preachers in da'wah becomes a determining factor in the process of communication with more persuasive messages so that effective communication emerges in preaching. In addition to science and expertise, language also greatly influences the delivery of persuasive messages. Often there are language problems faced by preachers when speaking (Malik \& Iriantara, 1994, p.82). Thus, the preacher should increase vocabulary and update knowledge.

This research is seen from the perspective of the source credibility theory proposed by Hovland, Janis and Kelley. The basic assumption of this theory is that a person can be more easily persuaded if the source is credible. Credibility in this theory contains two elements, namely expertise and trust possessed by the source or communicator. The attraction is one of the complementary components in establishing the credibility of a source or communicator (Rakhmat, 2012: 256).

Research on the credibility of preach was conducted previously by Mariyatul Norhidayati Rahmah (2017). The similarity of this research with this research is that they both examine the credibility of preachers, but the research is more focused on the exemplary attitudes of the preacher as a communicator in 
implementing the attitude or method of preaching Rasulullah SAW (Rahmah, 2017).

This study examines how a preacher builds and increases his credibility in the post-truth era. This era is an era that no longer believes in the truth, but rather believes in a trending opinion. The more propaganda content that is served on social media today, the easier it is for people to consume knowledge without verification or confirmation of the source that conveys the information or knowledge. Based on the background of the problem described above, this research aims to understand and describe the way in building and increasing its credibility, which influences you to receive messages, and also follows the invitations and suggestions delivered. The novelty of this research is the discovery of a format of credibility based on social media that developed in the post-truth era.

The research used is a descriptive-qualitative type. This type of research is interpretive (using interpretation) which involves many methods, in examining research (Mulyana \& Solatun, 2008, p.5). This descriptive method is used to systematically and deeply describe the facts or characteristics of a particular field in the study of a preacher's efforts to increase his credibility in the post-truth era. The subjects in the study were preachers in the Wonocolo sub-district of Surabaya City who had information about how they increased their credibility as preachers in the post-truth era. The criteria for informants are more directed to preachers who are actively preaching on social media, who can know the development of the times and technology, to facilitate in providing in-depth information about how to increase the credibility of a preacher. The main source of research data is in the form of words from interviews with informants who have set criteria. Data analysis was performed using the Miles and Huberman model which was divided into four components, namely data collection, data reduction, data presentation, and finally concluding (Miles \& Huberman, 1992, p.92).

\section{RESULT AND DISCUSSION}

The results of research on preachers who are the subject of this study states that in building and increasing the credibility of a preacher in preaching in the posttruth era at this time, there are four important ways, namely to build a clear scientific sanad, there is a balance of literacy, the results of written works scientific, and rhetorical management that needs to be applied when preaching.

\section{Building a Clear Scientific Sanad}

The term sanad consists of three letters namely sin, nun, and dal, and can be interpreted as the process of gathering or gathering something with others. Etymologically Sanad is something that is used as a base or footing. While jumhur ulama hadith experts say that, sanad means a chain or series of narrators of traditions that can link to the text of the hadith or matan hadith (Anshori, 2016, 
p.299). Based on the definition of sanad according to the hadith expert, scientific sanad is the link of a teacher, from the teacher, and continues to connect with the previous teacher until finally the science is connected and can be accounted for.

Sanad Scientific is an intellectual transmission that is often referred to by people among pesantren. Non-pesantren general education institutions do not go deep into the use of the term scientific knowledge. A piece of knowledge is obtained only through the teacher alone, and not to mention the sequence of teachers, teacher teachers and so on. It might even be obtained by self-taught knowledge, by learning certain sciences by yourself through books that are read (Sanusi, 2013, p.63). According to the views of previous scholars, it is very important to know the origin of religious teaching, especially related to preaching, so that what is obtained by mad'u can be accounted for. A cleric named Abdullah Bin Al-Mubarok once mentioned that "Isnad is a part of religion. Without sanad, then anyone will speak whatever he wants ". The teachings of Islam are passed on from generation to generation through scholars to his students. All these teachings are expected to be connected to the Prophet Muhammad, so that the teachings of Islam can be maintained (Syauqi, 2018, p.1).

Da'wah activities in the era of the use of social media are often found by preachers who preach without a clear scientific sanad. It even adds to the complexity of preaching on social media because it is prone to give birth to conflicts caused by the credibility and inconsistency of the preacher (Thaib, 2019, p.40). For a preacher, sanad science is the most important capital he must have. As someone who is considered to have competence in religious knowledge, a preacher must truly possess knowledge before giving. Imam Ahmad bin Hambal stated the importance of a preacher to have the knowledge, which exceeds eating and drinking in his daily life (Zaidan, 2002, p.327). A preacher is required to have clear scientific origins. All acts of charity will only be accounted for by the person who does it. Thus in a preacher also attached that in each preaching, must be included with a reference as a reference material preaching, as said by one informant as follows:

"In Islam, someone who performs worship must have a clear reference. So not only do worship but a preacher also in preaching must have a clear reference. If there are two Islamic references, namely the proposition naqli and there is the argument 'aqli, then in the case of da'wah is also the same. A preacher takes these references with a clear intermediary. In a sense, when I express an argument or source in preaching, then I always to express "that according to my teacher ...." "that from the story of my teacher who was told again from his teacher was like this ..." now, from so that my teacher can continue to connect again, then connect again, eventually reaching Rosulullab $S A W$ "(Informant A, 2019).

Science occupies a very important position in the teachings of Islam. This can be seen by the many verses of the Koran that look at people who know with a high position and very noble, is no exception to the preachers. Besides being 
contained in the verses of the Qur'an, many of the Prophet's traditions also encourage his people continue to study, and one of them is by listening to the preaching lectures (Sarifandi, 2014, p.62). In preaching, a preacher must have a clear knowledge of its structure and then be able to connect with what is taught by the Prophet Muhammad. The credibility of a preacher can be seen by the expertise of preachers in delivering propaganda material, by including the pedigree of the scientific Sanad. The expertise which can then give confidence to made to follow the teachings and invitations $d a^{\prime} i$.

The Book Ta'limul Muta'allim explains that "seeking legal knowledge is obligatory for every Muslim" (Al-Zarnuji, 2018, p.15). The meaning of seeking knowledge meant in this case is to find a teacher who is clear in his knowledge and expertise. As the informant said:

"Searching is going to go ... looking for teachers who have clear knowledge ... we cannot easily browse, synchronize, then make references when preaching," (Informant A, 2019).

The clarity of the scientific sanad, has been exemplified by previous 'scholars'. Although only to study the Qur'an, they can travel great distances to meet a teacher so that they can connect to their scientific knowledge. As an example of the story of a student of Imam Malik bin Anas, Muhammad bi Idris bin Al-Abbas As-Shafi'i who is better known by Imam Shafi'i (Cholil, 1995, p.245). Imam Syafi was a young Quraysh whose nasab was connected to the Prophet in the path of Abdu Manaf. He was born in the Palestinian Ghaza, which later grew and developed in Mecca. Little Imam Shafi'i is already famous for his intelligence and genius. In Makkah, he studied Fiqh with a Mufti of Makkah namely Shaykh Muslim bin Kholid Az-Zanjiyi. Then he went to Medina to explore the science of Fiqh to Imam Malik bin Anas. He recited the book Al-Muwattha 'and memorized it in 9 nights. Imam Malik greatly admired Imam Shafi'i after seeing how genius a 15-year-old orphan boy had been able to complete his memorization by 9 nights. Vice versa, Imam Shafi'i also admired his teacher, Imam Malik. And he Imam Syafii expressed admiration for his teacher after becoming an Imam with the famous statement that reads "if there were no Malik bin Anas and Sufyan bin Uyainah, surely knowledge would be lost from the Hijaz". In addition to Makkah and Madinah, Imam Syafii also studied and met directly with his teachers, the 'ulama' outside his countries such as Yemen, Iraq, and Egypt (Syahroni, 2019, p.5). Another example is also exemplified by the story of a journey to study a young man who came from the Jailan region named Muhyiddin Abu Muhammad Abdul Qodir ibn Abi Shalih Al-Jailani who is currently famous and famous by the name of Sheikh Abdul Qodir Al-Jailani. Sheikh Abdul Qodir was very fond of studying since he was young, and among his teachers were, Shaykh Abil Khattab AlKalwadzani, Shaykh Abi Al-Wafa 'and Shaykh Abil Husein Abu Ya'la (Haque, 2007, p.57), Abu al Khair Hamad bin Muslim Ad-Dabbas and many of his other teachers so that he received a diploma and high position from Al-Qodhi Abu Said 
Al-Mukharami. With enthusiasm and effort, the teenage Sheikh Abdul Qodir tried to gain religious knowledge by leaving Jilan and heading to Baghdad. He also studied with the Prophet Khidzir a.s for 3 years. In the first year the shaykh was still given food and drink, the second year he was only given food, and in the third year, he did not eat and did not drink until he was finally graduated. Sheikh Abdul Qodir spent 32 years studying and studying various types of knowledge and then he began to preach and establish a madrasa in $520 \mathrm{AH}$. During his study period, he experienced long-suffering and endured the narrowness of life that was completely lacking (Humaidi, 2018, p.64).

History of the search for knowledge above shows the importance of scientific sanad that can build the credibility of a communicator $\left(d a^{\prime} i\right)$. From the perspective of source credibility theory, preachers who have a clear sequence of scientific sanitation have a degree of expertise and quality that can be trusted more because they have competence in the field of religion or science that is occupied. Da'wah is not just talking about faith and monotheism, but it must already talk about economics, politics, the environment, and so on (Hakim, 2018, p.159), the practice of da'wah transforming Islamic values in various dimensions of life (Fatoni \& Tedi, 2017, p.210). With expertise and trust that is owned, a preacher already has the capital in matching the audience, and the public tends to accept and easily understand what the preacher conveys because he already has reliable credibility (Rakhmat, 2012, p.257).

\section{Building a Literary Balance between Religious Science and General Knowledge}

Literacy can be understood as a person's ability to read and write. The lack of literacy is one of the problems of society in the post-truth era and information globalization. UNESCO noted that the reading interest index in Indonesia had only reached 0.001 , meaning that in 1000 people there was only one person who had an interest in reading. The level of literacy in Indonesia is also ranked 64 out of 65 countries that have been surveyed by UNESCO. And one more sad fact that the reading level of Indonesian students ranks only 57 th out of 65 countries (Permatasari, 2015, p.147). Along with the development of science and technology, success in the education process is also determined by the literacy competencies of the learners (Irianto \& Febrianti, 2017, p.640). Likewise in da'wah, a preacher must also have a balance in literacy to achieve effective da'wah.

In addition to having a clear sanad or scientific structuring, a preacher must have extensive literacy skills and also use literature not only from the internet but literary values in baboon books such as books of turost participate included.

"We really should not be encouraged by the world of the internet ... it may be a reference on the internet to study the development of the times in this era of globalization, but we must not also leave ancient literature, such as sources of jurisprudence, hadith, etc. so. 
Thus, the community will be able to believe what we are talking about. "(Informant B, 2019).

A preacher who uses literature with books or ancient books is easily accepted in the community because he is considered to have a breadth of religious knowledge and ability in terms of broad science.

"... in fact in terms of literature, we Muslims who clash with previous 'ulama' should also be matched with books of baboons, so that not only we know about the scientific origins, but we can share them too. with other people, even though later other people might not find the baboon books... "(Informant B, 2019).

The development of technology and information has given birth to a very interesting phenomenon in people's lives. With the advent of gadgets, literature is easily available anywhere, anytime, and under any circumstances. Easy access to social media provides a great opportunity for hoax news circulation or other knowledge (Al-Walidah, 2017, p.318). The existence of hoax news is the other side of the impact of technology, on the other hand, technology can bring progress and prosperity in the industrial field (Kusnawan, 2016, p.367). Seeing this phenomenon, according to the views of previous Islamic scholars, it should always be in contact with the Islamic classic books, which are forms of collision or hope for blessings with the original sciences and ancient sciences and synergized with general knowledge which is developing. Seeing the state of society in this posttruth era, as a preacher, one cannot only use ancient literature as told by one informant,

".. that the Qur'an cannot be forced ... as a da'i, we must be able to understand mad'u. When the Qur'an includes the literature of ancient books, then as a preacher it must be able to relate it to the current conditions, people now will not be able and willing to accept knowledge which at that time was indeed the situation of the ancients. Because the times are different ... so it is only natural ... therefore, the preacher must be able to bring the teachings of the previous 'ulama' into the life and condition of today's society ... "(Informant B, 2019.

A $d a^{\prime} i$ who delivers preaching messages in the post-truth era and relies only on the footing of ancient literature on social media is certainly not an appropriate strategy. It will even give birth to bad opinions for the preacher. Therefore, a preacher in the post-truth era needs to build a balance in literacy. $D a^{\prime} i$ 's credibility must be built through a balance of literacy between religious knowledge and general knowledge that continues to grow. With extensive knowledge and insight about religion and general knowledge possessed, a preacher will be able to build trust in the public (audiences) in receiving the message of preaching. According to credibility theory, when trust has been obtained from mad'u, then the attraction will also increase. A preacher or communicator who wants to influence others should start by emphasizing the similarity between himself (his knowledge) with the conditions being faced by mad'u (Rakhmat, 2012, p.262). 


\section{Building Da'i Credibiltas through Scientific Writing}

Islamic da'wah experiences a very diverse development dynamics, ranging from characteristics, standardization, and preaching provisions to the social reality of community life as the target of da'wah $\left(\operatorname{mad}^{\prime} u\right)$. By seeing social conditions that are developing very rapidly, it demands the development of a systematic pattern of da'wah movements for preachers (Kango, 2014, p.105). Very ironic, when da'wah can only be viewed through lectures on the stand. Thus, in addition to multiplying reading reference books, a preacher must also have a paper. This is consistent with the acknowledgment of an informant as follows:

"... at the moment there are many preachers who only just preach, but do not want to read and write. Even though a preacher is required to read and write. As one professor said that "I exist because I write. Because people only talk, it will quickly disappear. "(Informant C, 2019).

Facts and problems that are currently happening are many appearances of preachers on social media whose scientific background is unknown. All can be accepted and consumed by the community just like that. It certainly contains maslahat (profit) and also madhorot (loss). The advantage is very clear, that da'wah can be spread to the wider community in various parts of the world. While the risk of loss, with the emergence of $d a^{\prime} i$ on social media, there will be popular over themselves so that the value of the sacredness of the $d a^{\prime} i$ has been considered to be a pious person (Efferi, 2013, p.106).

A preacher who has written work, whether in the form of books or journals, articles, etc., will be easier to be known by the public at large without leaving the value of the sacredness of a preacher. This is where a preacher's self-image will be awakened and seen by the public. Writing is also one way to improve self-image or credibility as a preacher. Only speaking capital would not be enough for a preacher. $D a^{\prime} i$ needs to write about ideas and ideas that have in his mind and outlined in the form of writings that can be published and read by the general public. Verbal words will be swallowed up by the development of the times, but writing will be remembered for all time. The era of technological progress must be followed by the ability to use the internet for the preachers (Muhaemin, 2017, p. 341). The internet can be used as a medium to work through writing.

The reality, at present, many preachers are only good at speaking or preaching verbally, but very few preachers who can read and write. At the time of friends, preaching was done not only by verbal speech, but also clever in inviting his people to walk straight with writing. For example, the Qur'anic verses are recorded as guidelines for human life (Efferi, 2013, p.108). Companions of the view that the teachings of Islam originating from the Qur'an are no longer effective if only delivered through oral (Ilhamni, 2017, p.140).

The results of scientific papers are the other side of a preacher. If referring 
to the scholars' earlier, none of which does have work. All of them wrote books that are probably currently used by many people as references. The writings of scholars earlier able to attract the attention of many people by being a source of scientific references. This is very different from the preachers today. Da'i currently lectures more in the absence of an article as a result of his work. For a preacher to improve his self-image and credibility must be done by writing work, it can be in the form of books, articles or journals which are now a contemporary work among academics.

\section{Building and Managing Da'wah-Based Rhetoric Based on Current Times}

A rhetoric is an important part of every individual's daily life. Whatever life background one has, they interact with others in their daily lives. Therefore, it should not behave badly in interactions with others (Maarif, 2015, p.5). As a communicator, a preacher can influence his communicant or madam when a preacher can process the techniques of delivering the message of preaching well. The ability to speak in public will be able to convince you to believe what is preached by the preacher. In this case, a preacher who is dealing with mad'u in the post-truth era must be able to rhetoric by the characteristics of the mad'e he is facing. The following is the statement of the informant:

"Besides literature, the next is rhetoric, sometimes in a study session, there are not only teenagers who join the Koran, but sometimes there are also some elderly people who attend. Therefore, how cleverly the preacher can process his rhetoric when in such circumstances "(Informant B, 2019).

The above data proves that da'wah is not easy to accept in all ages, educational backgrounds, genders, and so on. Da'wah has its own space and portions which are adjusted to the characteristics of the da'wah target. Therefore, in the delivery of da'wah, the choice of diction should be easily understood by various groups. The following informant's statement as follows:

"So, when we are in an assembly, why do they all mix, meaning in the sense of various groups, we must be very clever in choosing diction in preaching, sometimes in the middle, it must be interspersed with jokes so as not to span. there are also times when there are a few in innuendos so that the preaching hits the hearts of pilgrims. "(Informant B, 2019).

Da'wah can be successful when the messages can be received among the madness. A preacher before giving a lecture, long beforehand it was necessary to examine carefully whether the mad'u he was going to face was homogeneous or heterogeneous, and whether there were also few or many. Effendy (2006) says in his book that a large number of honey, will tend to be more emotional because there must be material factors that could be driving his emotions to act emotionally. While the number of mad'u tends to be small, there are many possibilities that they are conducive and also rational. Because of the comfort factor in learning, without any noise such as the tightness of the place, or so forth. 
Honey with all its characteristics will be closely related to the message that will be conveyed by the preacher to them and also the selection of the right diction to use. This is where a da'wah will succeed if the message or material delivered by a preacher is by your interests. And it will also succeed if the language or diction choice used can be easily understood by all the madu. It is possible to be able to use regional languages to be more communicative, if indeed the majority is low educated, such as villagers for example (Effendy, 2006, p.64).

Based on the above data exposure, the results of this study indicate that in preaching, a preacher must increase his credibility through several ways, namely by including a clear scientific sanad, using literary baboons (classical books) as a capital to convince mad'u, has a paper, and the last is the management of rhetoric by the conditions and conditions of mad'u that is being faced.

The theory of source credibility explains that credibility contains two main elements or components, namely expertise and trust that is owned by the source or communicator, and also the attractiveness of its supporting components (Rakhmat, 2012, p.257). In connection with the inclusion of a clear scientific sanad in da'wah, a preacher or communicator can reduce your doubts about the topic or preaching that he conveys so that you can also find out the scientific source of a preacher who is made a role model.

In addition to scientific matters, preachers in the Wonocolo District, Surabaya also used baboon literature (classical books) as capital to increase their expertise in da'wah. Not only encouraged by references on the internet. Ancient references also need to be reviewed and reproduced to avoid a misunderstanding in science.

Along with the times, references from the internet also need to be consumed by a preacher to add insight knowledge so that it can adjust to the current condition of mad'u. The rapid technological advances marked by the rapid flow of information and knowledge received by the public, making humans today become very thirsty for information and look for it through a Google engine that can receive more than 4 million information searches in every minute (Muttaqien, 2015 , p.1) . In Islamic da'wah, information has a strategic position as a means to distribute Islamic values to the wider community.

The final way to increase credibility is to manage rhetoric by your circumstances. Every communicator certainly can process different rhetoric. This can be a characteristic of a preacher. It may be that in preaching material preachers use language that is relaxed and a lot of humor tucked in it, or also a preacher who sees the condition of the majority is teenagers, then preachers would be better to use millennial languages or the popular one now. Basically, the Islamic da'wah returns to what is the purpose of the da'wah and what it wants to achieve. In the Qur'an it is stated that "the general purpose of da'wah is to invite humanity (including believers and infidels or polytheists) to the right path and blessed by Allah SWT, so that they can live happily and prosperously both in the world and 
in the hereafter (Aziz, 2009, p.134).

\section{Supporting Components of Da'i Credibility}

There are three important elements as a support to increase the credibility of a preacher in carrying out his preaching in the post-truth era, namely expertise, trust, and attractiveness (Grace, 2012, p.256).

First, expertise. Expertise is the impression that is formed by the communicator about the communicator's ability to the topic being discussed (Rakhmat, 2012: 254). In this case, the expertise of the preacher or communicator is closely related to the evaluation of the teacher or communicant regarding the ability of the preacher in delivering the message of preaching and also the nature and mastery of the material delivered. Da'i's expertise in this study can be reflected based on the level of knowledge possessed by da'i. Mad'u, in this case, can see how much the level of the ability of preachers based on the preacher's shrewdness in delivering propaganda material by the needs of mad'u and the continuity between the knowledge conveyed based on previous literature with the comparison of internet literature as an implementation of the social life of the community this time. As mentioned in Qowaidul Fiqhiyah "Al-Muhafadhotu" Alal qodimis sholih, wal akbdzu bil jadidil Ashlab "which has the meaning of preserving good old traditions, and adopting new traditions that are better (Rosi, 2018: 49). Keep using old references as taught by the scholars' before by linking with the current human condition for capital in da'wah so that you will be able to accept da'wah well.

Second, Trust. Trust is the impression of the audience about the communicator related to his character and personality. Reliable communicators are communicators who are considered honest, sincere, moral, fair, polite or ethical (Rakhmat, 2012, p. 254). Mad'u will believe in the da'i depending on the character possessed by the da'i itself. If the preacher is considered honest and sincere in conveying information, moral, fair, ethical, and also polite in making statements and acting, then you will believe it. Your belief in preachers can be built by seeing how preachers deliver their preaching. Da'i preaches, clearly, and can take responsibility for what is said when preaching by including clear references, and delivery of preaching with diction by the circumstances of mad'u, such da'i is as a person who honest and able to build trust mad'u by looking at that side.

Third, Attractiveness. The last component that influences the credibility of a preacher is attractiveness. Attractiveness is one of the most important factors in determining the effectiveness of persuasion done by the communicator. Thus, physical attraction is very different from charisma. A preacher can be attractive, but not charismatic. Likewise, many charismatic preachers look less attractive (Sigar, Londa, \& Tulung, 2017: 10). Communicator attraction is the attractiveness of physical appearance (physical) and also psychological appeal. Physical 
appearance is one of the attractions of a preacher. A physical appearance of a preacher will be able to influence how your perception of him. Not only affects the communicant, the physical attractiveness of a preacher is also able to create a different personality for himself. Da'i who are physically attractive, social groups will certainly get attention from their masts (Sigar, Londa, \& Tulung, 2017, p.6).

Psychological Attraction is aspect usually consists of similarity, familiarity, or liking. Similarity or similarity is intended so that people can be attracted to communicators because of the similarity of demographics, such as language, religion, area of origin, and ideology. Familiarity means a well-known communicator will be more accepted by the audience than those who are not known. Communicators who are known for their expertise will be easily accepted because the audience will not doubt their abilities and honesty. Favorite or liking means that the communicator is preferred because of his physical appearance, the similarity, or well-known will have more attractiveness (Rakhmat, 2012, p.264).

Various methods can be done to attract the attention of honey. Based on the results of this study, mastery of rhetoric in preaching is one of the emergences of attraction for a preacher. Preaching by seeing the state of mad'u first, will cause sympathy for mad'u to listen to lectures. Like this can be seen in millennial preachers today who can attract the attention of teenage fans. A preacher must increase his charisma through increasing the integrity of a good personality, having strong principles, being honest in life, and always being strict in preaching (Tajiri, 2017, p.293).

The next component of credibility according to Koehler, Annatol, and Applbaum (Rakhmat, 2012, p.260) is dynamism, sociability, co-orientation, and charisma. Dynamism is about communicating, being passionate, passionate, active, assertive, and also brave. A preacher must expressly dare to preach. This is where the need for clear science as a form of accountability. Sociability is related to the impression that the communicant has about the communicator as a cheerful and sociable person. It's only natural as a preacher to have a friendly nature. This will form the perception of mad'u, so there will be an attraction from mad'u to da'i. Coordination is related to the communicant's impression of the communicator as a person who represents the group and the values of the communicant. A preacher as someone who is respected in a group is supposed to create harmonious relationships within the group. Charisma is related to the extraordinary nature possessed by communicators. Expertise in da'wah, extensive knowledge, is one form of extraordinary qualities possessed by a preacher.

The era and the development of post-truth are very influential in the world of da'wah. Preaching activities at this time can be carried out by Muslims wherever he is and can also be consumed on various social media without space and time restrictions. For those who are narrow-minded, it will be very easy to use a variety of reasons to consume da'wah on social media because they feel that what is said on social media is by the conditions at the moment. Though it is possible, what is 
on social media is very different from the facts and scientific perspectives.

\section{CLOSING}

A da'i requires in the post-truth era has clear scientific knowledge so that people do not easily doubt their knowledge, and also as a means to be held accountable later. Da'i needs to balance the literature between references to follow the current trend, namely by taking it from the internet and also not to abandon previous references by reviewing classic books or baboon books. A preacher will be better known and also has an attraction when having a paper in the form of books, journals, or articles. Anyone can do da'wah based solely on verbal speech or by speaking alone. However, it will be different when preaching as well as having published papers. This will further enhance preacher's self-image. Finally, in increasing the credibility of a preacher it is necessary to have the rhetorical ability in choosing good diction, by the situation that is being faced with mad'u. Mad'u will be more interested in responding to messages that are by their wishes because they feel suitable for the topic being discussed by da'i.

The results of this research need to be developed more deeply so that it can add to the scientific treasures for the community, especially in the field of da'wah. As technology and social media develop, so does the level of human intelligence. This is one form of the impact of globalization.

\section{BIBLIOGRAPHY}

Al-Walidah, I. (2017). Tabayyun di Era Generasi Millenial. Jurnal Living Hadis, 2(2), 317-344. DOI: 10.14421/livinghadis.2017.1359

Anshori, M. (2016). Kajian Ketersambungan Sanad (Ittişāl Al-sanad). Jurnal Living Hadis, 1(2), 294-323. DOI: 10.14421/livinghadis.2016.1123

Aziz, M. A. (2009). Ilmu Dakwah. Jakarta: Kencana.

Al-Zarnuji, B. (2008). Ta'lim al-muta'allim: Tariq al-ta'allum [Learning instruction for students learning]. Surabaya, Indonesia: Al Miftah.

Beebe, S. A., \& Beebe, S. J. (2005). Public speaking handbook. Allyn \& Bacon.

Cangara, H. (2008). Pengantar Ilmu Komunikasi. Jakarta: PT Raja Grafindo Persada.

Cholil, M. (1995). Biografi Empat Serangkai Imam Mazhab. Jakarta: Bulan Bintang.

Effendy, O. U. (2000). Ilmu, Teori dan Filsafat Komunikasi. Bandung: Remaja Rosdakarya.

Effendy, O. U. (2006). Ilmu Komunikasi Teori Dan Praktik. Bandung: Remaja Rosda Karya

Efferi, A. (2013). Profesionalisasi Da'i di Era Globalisasi. AT-TABSYIR: Jumal Komunikasi Penyiaran Islam, 1(1), 91-120. Retrieved from 
https://journal.iainkudus.ac.id/index.php/komunikasi/article/viewFile/4 $28 / 452$

Fatoni, U. \& Tedi, E. (2017). Dakwah Literasi Ustadz Giovani Van Rega: Analisis Imbauan Pesan Dakwah. Jurnal Komunikasi Islam. 7(2), 209-225 DOI: 10.15642/jki.2017.7.2.209-225

Hakim, R. R. R. (2018). Tantangan Dakwah dalam Media Teknologi Komunikasi Di Era Globalisasi. Jurnal Ilmu Dakwah, 38(1). 143-161 DOI: 10.21580/jid.v38.1.3974

Haque, M.A. (2007). 100 Pablawan Muslim yang Mengubab Dunia. Terjemahan: Iro Puspitorini. Yogyakarta: Diglosia.

Hariyanto, H. (2018). Relasi Kredibilitas Da'i Dan Kebutuhan Mad'u Dalam Mencapai Tujuan Dakwah. Tasâmuh, 15(2), 61-82. DOI: 10.20414/tasamuh.v15i2.212

Hartono, D. (2018). Era Post-Truth: Melawan Hoax dengan Fact Checking. Presented at the Prosiding Seminar Nasional Prodi Ilmu Komunikasi., Jakarta: Universitas Mercu Buana.

Humaidi, A. (2018). Adab Pendidik dan Peserta Didik Perspektif Syeikh Abdul Qodir Al-Jailani dan Relevansinya dengan Pendidikan Islam Saat Ini. Bachelor Thesis. UIN Raden Intan Lampung

Ilhamni (2017). Pembukuan Al-Qur'an pada Masa Usman Bin Affan. Jurnal Ulunnuba, 6(2), 130-142. DOI: 10.15548/ju.v6i2.596

Irianto, P. O., \& Febrianti, L. Y. (2017). Pentingnya Penguasaan Literasi Bagi Generasi Muda dalam Menghadapi MEA. Proceedings Education and Language International Conference, 1.

Jatmiko, M. I. (2019). Post-Truth, Media Sosial, dan Misinformasi: Pergolakan Wacana Politik Pemilihan Presiden Indonesia Tahun 2019. Jurnal Dakwah Tabligh, 20(1), 21-39. DOI: 10.24252/jdt.v20i1.9529

Kango, A. (2014). Jurnalistik dalam Kemasan Dakwah. Jurnal Dakwah Tabligh, 15(1), 105-114. DOI: 10.24252/jdt.v15i1.341

Kusnawan, A. (2016). Dakwah pada Masyarakat Teknologi. Ilmu Dakwah: Academic Journal for Homiletic Studies, 10(1), 355-374. DOI: 10.15575/idajhs.v10i2.1557

Maarif, Z. (2015). Retorika Metode Komunikasi Publik. Jakarta: Raja Grafindo Persada.

Malik, D. D., \& Iriantara, Y. (1994). Komunikasi Persuasif. Bandung: Remaja Rosdakarya. 
Mcintyre, L. (2018). Post-Truth. Cambridge, MA: MIT Press.

Miles, M. B., \& Huberman, A. M. (1992). Analisis Data Kualitatif. Terjemahan: Tjetjep Rohendi Rohidi. Jakarta: UI-Press.

Muhaemin, E. (2017). Dakwah Digital Akademisi Dakwah. Imu Dakwah: Academic Journal for Homiletic Studies, 11(2). 341-356. DOI: 10.15575/idajhs.v11i2.1906

Mulyana, D. (2008). Komunikasi Efektif. Bandung: Remaja Rosda Karya.

Mulyana, D., \& Solatun (Ed). (2008). Metode Penelitian Komunikasi. Bandung. PT Rosdakarya.

Muttaqien, M. A. (2015). Kreativitas Dakwah di Tengah Masyarakat Modern. Retrieved 2015, October 19 from https://www.dakwatuna.com/2015/10/19/76017/kreativitas-dakwah-ditengah-masyarakat-modern/amp/

Permatasari, A. (2015). Membangun Kualitas Bangsa Dengan Budaya Literasi. Prosiding Seminar Nasional Bulan Bahasa UNIB, Bengkulu.

Rakhmat, J. (2012). Psikologi Komunikasi, Bandung: Remaja Rosdakarya

Rahmah, M. N. (2017). Kredibilitas Juru Dakwah sebagai Komunikator. Alhadharah: Jurnal Ilmu Dakwah, 12(24), 1-13. DOI: 10.18592/alhadharah.v12i24.1758

Rosi, F. (2018). Konsep Pembaharuan Kurikulum Pendidikan Pondok Pesantren. Widya Balina 3 (5), 105-125. Retrieved from https://journal.staidenpasar.ac.id/index.php/wb/article/view/13

Saifuddin, A. (1995). Sikap Manusia Teori dan Pengukurannya. Yogyakarta: Pustaka Pelajar Offset.

Sanusi, U. (2013). Transfer Ilmu di Pesantren: Kajian Mengenai Sanad Ilmu. Jurnal Pendidikan Agama Islam, 11(1), 61-70. Retrieved from http://jurnal.upi.edu/file/05_Transfer_Ilmu_di_Pesantren__Uci_Sanusi.pdf

Sarifandi, S. (2014). Ilmu Pengetahuan dalam Perspektif Hadis Nabi. Jurnal Ushuluddin, 21(1), 62-82. DOI: 10.24014/jush.v21i1.727

Sigar, H. S., Londa, N., \& Tulung, L. E. (2017). Persepsi Jemaat terhadap Kredibilitas Pelayan Khusus sebagai Komunikator (Studi di Jemaat Gmim Nafiri Walewangko, Kecamatan Langowan Barat, Kabupaten Minahasa)". ACTA DIURNA KOMUNIKASI, 6(3), 1-13. Retrieved from https:// ejournal.unsrat.ac.id/index.php/actadiurnakomunikasi/article/vie $\mathrm{w} / 17377$ 
Syahroni, A. (2019). Pembahasan Metode Pemahaman Hadis Imam Syafi'i. Aktualita: Jurnal Penelitian Sosial Keagamaan, 9(1), 1-16. Retrieved from http://ejournal.annadwahkualatungkal.ac.id/index.php/aktualita/article/v iew $/ 61$

Syauqi, M. I. (2018). Peran Fundamental Sistem Sanad bagi Ajaran Islam. Retrieved from https://islam.nu.or.id/post/read/85590/peranfundamental-sistem-sanad-bagi-ajaran-islam

Syuhada, K. D. (2018). Etika Media di Era Post-Truth. Jurnal Komunikasi Indonesia, $75-79$.

Retrieved from http://journal.ui.ac.id/index.php/jkmi/article/view/8789/pdf

Tajiri, H. (2017). Rijal al-Da'wah: Studi Faktor Karismatik Praktisi Dakwah di Kota Bandung. Ilmu Dakwab: Academic Journal for Homiletic Studies 11(2), 293310. DOI :10.15575/idajhs.v11i2.1914

Thaib, E.J. (2019). Problems of Da'wah in Social Media in Gorontalo City Communities. Ilmu Dakwah: Academic Journal for Homiletic Studies. 13(1), 7353. DOI :10.15575/idajhs.v13i1.4412

Zaidan, A. K. (2002). Ushulud Da'wah. Beirut-Lebanon: Ar- Risalah. 